\title{
Study of the Nuclear Volume of Testicular Cells of Rats Receiving Ofloxacin Through Lactation
}

\author{
Estudio del Volumen Nuclear de Células Testiculares de Ratas \\ que Recibieron Ofloxacin Durante la Lactancia
}

\author{
"Vânia Del'Arco Paschoal; **Andréa Batista Rossit; ${ }^{* * *}$ Luiz Onivaldo Bizutti; \\ ****** Rodrigo Monteiro; ${ }^{* * * * * * *}$ João Armando Padovani Junior \& ${ }^{* * * * * *}$ Reinaldo Azoubel
}

PASCHOAL, V. D. A.; ROSSIT, A. B.; BIZUTTI, L. O.; MONTEIRO, R.; PADOVANI JR., J. A. \& AZOUBEL, R. Study of the nuclear volume of testicular cells of rats receiving ofloxin through lactation. Int. J. Morphol., 25(3):603-608, 2007.

SUMMARY: Ofloxacin presents an ample spectrum of antimicrobial action, including combating Mycobacterium leprae, and is currently employed as a substitute when the use of rifampicin is impossible. The objective of this work was to study alterations in testicular cell nuclei of suckling rats, whose dams were submitted to oral application of ofloxacin, and respective control groups. The method utilized was morphometry by the karyometric technique. The main structures observed in histological preparations of the testicles were interstitial cells, spermatogonias, and sustentacular cells. 10 Wistar rats were utilized, four treated and five controls, in the period of the first 25 days of life, whose dams received ofloxacin $12 \mathrm{mg} / \mathrm{Kg}$ of body weight / day orally, before being killed on the $25^{\text {th }}$ day after birth. The karyometric study of interstitial cells and spermatogonias revealed that there were no changes in the form of their nuclei ( $p>$ 0.05). Since sustentacular cell nuclei presented increased major diameter, minor diameter, mean geometric diameter, volume, area, volume/area ratio and perimeter, as well as an augmented and statistically different eccentricity $(\mathrm{p}<0.05)$ in suckling pups whose dams were administered ofloxacin, the nuclei presented larger size and more elongated form. It was concluded that the sustentacular cells were more sensitive to the ofloxacin effect at the administered dose.

KEY WORDS: Quinolones; Ofloxacin; Morphology; Karyometry; Nuclear volume, Testicle; Lactation; Sustentacular cells; Rat.

\section{INTRODUCTION}

Ofloxacin is a quinolone that has shown to be an efficient bactericidal drug for the treatment against Grampositive and Gram-negative microorganisms, as well as against anaerobic organisms (Hopkins et al., 2001; Meiland et al., 2001).

Ofloxacin acts on infections of the respiratory and urinary tract, pelvic inflammatory diseases, skin infections, osteomyelitis, colitis, and on sexually transmitted diseases that have chlamydia as an etiologic agent (Neu, 1992, 1997; Paschoal et al., 2003). In cases of genitourinary affections, it is used in the dose of $400 \mathrm{mg} /$ day, from 10 to 14 days, helping to avoid complications in future pregnancies and preventing reinfections. Researches with quinolones have revealed toxicity in rat and rabbit fetuses, whose dams received high doses of quinolones $(810 \mathrm{mg} / \mathrm{kg}$ in rats and $50 \mathrm{mg} / \mathrm{kg}$ in rabbits), by relating decrease in body weight gain, difficulties in bone growth, and arthropathy in young animals. However, such effects haven't been verified in rats who were administered doses of up to $360 \mathrm{mg} / \mathrm{kg}$ (Watanabe et al., 1992; Linseman et al., 1995).

In pregnant women who used ciprofloxacin $(400 \mathrm{mg}$ / day), perfloxacin (800 mg/day), and ofloxacin ( $800 \mathrm{mg} /$ day), the drugs crossed the placenta, entered breast milk presenting considerably high levels (Giamarellou et al., 1989).

On the other hand, studies demonstrate that, because of their toxic effect, the use of ciprofloxacin, perfloxacin, and ofloxacin in young animals (rats and rabbits) can lead to

* Department of Nursing in Collective Health and Vocational Guidance at Faculdade de Medicina de São José do Rio Preto, Brasil.

** Department of Dermatologic, Infectious and Parasitary Diseases at Faculdade de Medicina de São José do Rio Preto, Brasil.

*** Technician of the vivarium at Faculdade de Medicina de São José do Rio Preto, Brasil.

***** Gratuated Student F.M. Rio Preto S.P., Brasil.

****** Associated Professor at F.M. Rio Preto S.P. Brasil.

${ }^{* * * * * * * *}$ Subinstitute Health Sciences Graduate Program Coordinator at Faculdade de Medicina de São José do Rio Preto, Brasil.

Financial support by BAP/FAMERP/2002 
malformation, development delay with knee arthropathy, tendinitis, and tendon rupture. They also demonstrate that dogs have high-sensitivity to the drug (Paschoal et al.).

Some authors observed both functional testicular impairment, such as decrease in sperm count and motility, and structural testicular impairment, such as cell lesions in rats (Paschoal et al.; Abd- Allah et al., 2000; Paschoal, 2002). Though quinolones don't provoke gene mutations (Mayer \& Bruch, 1986), recent studies reveal that the use of this antibiotics during pregnancy in young females must be throughly researched (Stahlmann \& Lode, 1999).

The aim of this study was to quantify, through karyometry, possible nuclear alterations in testicular cells of suckling rats, whose dams received doses of ofloxacin.

\section{MATERIAL AND METHOD}

After the approval by the Animal Experimentation Ethics Committee at FAMERP - Faculdade de Medicina de São José do Rio Preto - SP - Brazil, four rats (Rattus norvegicus, of the Wistar strain) were used, as well as five control animals, born after the mating of six virgin females and two males of the same pedigree.

The drug used was ofloxacin in the dose of $12 \mathrm{mg} / \mathrm{kg}$ body weight, via a gastric tube. We opted for the use of the therapeutic dose, considering that the administered dose to treat an human adult (of up to $70 \mathrm{~kg}$ ) is of $800 \mathrm{mg} /$ day, from 7 to 14 consecutive days.

From the first to the $25^{\text {th }}$ day after birth, during lactation (pre-puberty period for the animal), $12 \mathrm{mg} / \mathrm{kg}$ body weight of ofloxacin solved in $4 \mathrm{ml}$ of distillated water were administered directly in the stomach of the dams with the aid of a gastric tube. The same quantity of saline solution was given to dams of the animals selected for the control group. Around the $25^{\text {th }}$ day after birth, five control males, and other four, whose mothers were treated, were chosen at random and, then, sacrificed by means of inhalation of sulfuric ether.

Histological technique. All the animals involved in this experiment were immersed in ALFAC fixing solution for 24 hours. After that, they were dried and weighed on a Mettler H64 balance, and immersed in alcohol 80\%. Next, the testicles were removed through an inguinal incision, and, then, fixed, cut transversely, dehydrated, cleaned, and embedded in paraffin. The paraffin inclusions were sectioned at $5 \mu \mathrm{m}$ thickness. Nine sections of each block were selected and stained with hematoxilin-eosin.

The main structures observed were tunica albuginea, interstitial cells, germinative epithelium, sustentacular cells, and spermatogonias.

Morphometric Technique: Karyometry. Images from the nuclei of testicular cells were projected on white paper with a final magnification of 1.240x using a H500-Hund Wetzlar optical microscope with immersion objective and Leitz Wetzlar camera lucida. Fifty nuclear images of each of the three types of studied cells were considered, totalizing the analysis of 150 nuclei for each animal. The camera lucida projected images that were, then, contoured with black pencil and had their major diameter (D) and minor diameter (d) calculated. From those diameters, the following nuclear parameters were estimated according to the formulas (Sala et al., 1981):

\begin{tabular}{|c|c|}
\hline Variables & Formulas \\
\hline Major diameter $(\mu \mathrm{m})$ & $\mathrm{M}=(\mathrm{D} \bullet \mathrm{d})^{1 / 2}$ \\
\hline Perimeter $(\mu \mathrm{m})$ & $\mathrm{P}=\left(\begin{array}{ll}\pi & 1 / 2) \cdot[3 / 2 \cdot(\mathrm{D}+\mathrm{d})-\mathrm{M}]\end{array}\right.$ \\
\hline Mean diameter ratio & $\mathrm{R}=\mathrm{D} / \mathrm{d}$ \\
\hline Volume $\left(\mu \mathrm{m}^{3}\right)$ & $\mathrm{V}=\pi \cdot 1 / 6 \cdot \mathrm{M}^{3}$ \\
\hline Area $\left(\mu \mathrm{m}^{2}\right)$ & $\mathrm{A}=\pi \cdot 1 / 4 \cdot \mathrm{M}^{2}$ \\
\hline Volume/area ratio & $\mathrm{V} / \mathrm{A}=2 / 3 \cdot \mathrm{M}$ \\
\hline Shape coefficient & $\mathrm{S}=4 \cdot \pi \cdot \mathrm{A} \cdot 1 / \mathrm{P}^{2}$ \\
\hline Contour index & $\mathrm{I}=\mathrm{P} / \mathrm{A}^{1 / 2}$ \\
\hline Eccentricity & $E=\left[(D+d)^{1 / 2} \bullet(D-d)^{1 / 2}\right] \cdot 1 / D$ \\
\hline
\end{tabular}

Statistical analysis. To analyse the parameters obtained from karyometry, a software described by Maia Campos and Sala (Department of Stomatology, Faculdade de Odontologia de Ribeirão Preto - SP - Brazil, USP) was utilized. The MannWhitney test was used for the statistical analysis, with a $95 \%$ confidence interval.

\section{RESULTS}

Target organ. The testicles were intra-abdominal, similar, with blood vessels and tunica albuginea presenting normal characteristics and numerous spermatic cords. They still didn't present lumen and had interstitial cells, sustentacular cells, spermatogonias and primary spermatocytes (undergoing cell division).

Morphometric results - Karyometry. The following results, presented in Tables I, II, III, refer to the data obtained through karyometry of testicular cells nuclei (interstitial, sustentacular and spermatogonias) from suckling rats, whose dams were submitted to ofloxacin. 
Interstitial cells (Leydig). In Table I, the data distribution were similar for all the variables from both studied groups; thus, there was no significant statistical difference $(p>0.05)$ when the Mann-Whitney test was used.

Spermatogonias. In Table II, when the values from the studied groups were distributed, they showed to be very similar for every analysed variable. The Mann-Whitney test did not present differences in data distribution $(\mathrm{p}>0.05)$.
Sustentacular cells (Sertoli). Table III presents the median values of the major diameter of Sertoli cells nuclei equal to $13,02 \mu \mathrm{m}$ for the control group, and $14.62 \mu \mathrm{m}$ for the treated group, as well as the median values of the nuclei minor diameter, $11.02 \mu \mathrm{m}$ for the control group and $12.29 \mu \mathrm{m}$ for the treated group. The median values of the mean nuclear diameter in 11,98 $\mu \mathrm{m}$ for the control group and $13.37 \mu \mathrm{m}$ for the treated group. The index for the control group nuclear volume medians was of $887.77 \mu \mathrm{m}^{3}$, and of $1182.00 \mu \mathrm{m}^{3}$ for the treated group.

Table I. Values from the kariometry of interstitial cells nuclei taken from suckling pups whose dams were submitted to application of ofloxacin (T), and control groups (C).

\begin{tabular}{|c|c|c|c|c|c|c|c|}
\hline \multirow[b]{2}{*}{ Variables } & \multicolumn{3}{|c|}{ Control group $n=250$} & \multicolumn{3}{|c|}{ Treated group $n=200$} & \multirow[b]{2}{*}{$\mathrm{p}^{*}$} \\
\hline & Mean & $\mathrm{Sd}$ & Median & Mean & $\mathrm{Sd}$ & Median & \\
\hline Major diameter $(\mu \mathrm{m})$ & 13.35 & 0.54 & 13.60 & 14.33 & 0.98 & 14.25 & $\mathrm{~ns}$ \\
\hline Minor diameter $(\mu \mathrm{m})$ & 8.87 & 0.37 & 8.80 & 9.47 & 0.31 & 9.51 & $\mathrm{~ns}$ \\
\hline Mean geometric diameter & 10.82 & 0.41 & 10.74 & 11.56 & 0.53 & 11.45 & ns \\
\hline Major/Minor & 1.55 & 0.05 & 1.54 & 1.58 & 0.07 & 1.60 & $\mathrm{~ns}$ \\
\hline Volume $\left(\mu \mathrm{m}^{3}\right)$ & 589.06 & 68.07 & 599.16 & 715.45 & 75.01 & 704.03 & $\mathrm{~ns}$ \\
\hline Area $\left(\mu m^{2}\right)$ & 93.87 & 7.40 & 93.02 & 107.50 & 9.37 & 105.18 & $\mathrm{~ns}$ \\
\hline Volume/ area & 5.91 & 0.24 & 5.87 & 6.31 & 0.20 & 6.34 & $\mathrm{~ns}$ \\
\hline Perimeter & 38.44 & 1.49 & 38.91 & 41.20 & 2.48 & 40.91 & $\mathrm{~ns}$ \\
\hline Eccentricity & 0.70 & 0.01 & 0.70 & 0.70 & 0.03 & 0.71 & $\mathrm{~ns}$ \\
\hline Contour index & 4.01 & 0.04 & 4.01 & 4.04 & 0.06 & 4.05 & $\mathrm{~ns}$ \\
\hline Shape coefficient & 0.79 & 0.01 & 0.79 & 0.78 & 0.02 & 0.78 & $\mathrm{~ns}$ \\
\hline
\end{tabular}

* Mann-Whitney Test; ns: non-significant at a $5 \%$ level.

Table II. Values from the kariometry of spermatogonias nuclei taken from suckling pups whose dams were submitted to application of ofloxacin, and control groups.

\begin{tabular}{|c|c|c|c|c|c|c|c|}
\hline \multirow[b]{2}{*}{ Variables } & \multicolumn{3}{|c|}{ Control group $n=250$} & \multicolumn{3}{|c|}{ Treated group $\mathrm{n}=200$} & \multirow[b]{2}{*}{$\mathrm{p}^{*}$} \\
\hline & Mean & $\mathrm{Sd}$ & Median & Mean & $\mathrm{Sd}$ & Median & \\
\hline Major diameter $(\mu \mathrm{m})$ & 11.20 & 0.58 & 11.40 & 12.83 & 0.72 & 13.41 & $\mathrm{~ns}$ \\
\hline Minor diameter $(\mu \mathrm{m})$ & 9.11 & 1.33 & 9.32 & 10.51 & 1.13 & 11.00 & $\mathrm{~ns}$ \\
\hline Mean geometric diameter & 10.08 & 1.32 & 10.33 & 11.59 & 1.25 & 12.20 & ns \\
\hline Major/Minor & 1.25 & 0.05 & 1.26 & 1.23 & 0.03 & 1.23 & ns \\
\hline Volume $\left(\mu \mathrm{m}^{3}\right)$ & 553.81 & 197.45 & 544.66 & 796.62 & 223.89 & 903.42 & $\mathrm{~ns}$ \\
\hline Area $\left(\mu \mathrm{m}^{2}\right)$ & 82.31 & 20.49 & 84.96 & 108.24 & 21.91 & 118.42 & $\mathrm{~ns}$ \\
\hline Volume/area & 6.07 & 0.88 & 6.21 & 7.00 & 7.75 & 7.35 & $\mathrm{~ns}$ \\
\hline Perimeter & 33.56 & 4.09 & 34.37 & 38.48 & 2.26 & 40.33 & $\mathrm{~ns}$ \\
\hline Eccentricity & 0.56 & 0.03 & 0.56 & 0.55 & 0.02 & 0.56 & ns \\
\hline Contour index & 3.76 & 0.04 & 3.77 & 2.90 & 1.68 & 3.72 & ns \\
\hline Shape coefficient & 0.88 & 0.02 & 0.89 & 0.89 & 0.01 & 0.89 & ns \\
\hline
\end{tabular}

* Mann-Whitney Test; ns: non-significant at a 5\% level. 
The nuclear area was estimated in $114.89 \mu \mathrm{m}^{2}$ and in $147.68 \mu \mathrm{m}^{2}$ for the group undergoing treatment. The median for the volume/area ratio was $7.35 \mu \mathrm{m}$ for the control and $8.19 \mu \mathrm{m}$ for the treated. The median values for the perimeters data of sustentacular cells nuclei was of 39.33 $\mu \mathrm{m}$, for the control group, and of $44.01 \mu \mathrm{m}$ for the treated group. For the eccentricity, the indexes were 0.47 and 0.51 , respectively for the control and treated groups. The difference in data distribution from one group to another is significant, indicating an increase in all the analysed variables of the treated group $(\mathrm{p}<0,05)$. The median values of the difference between major and minor nuclear diameters of sustentacular cells were of $1.16 \mathrm{~mm}$ for the control group and $1.19 \mathrm{~mm}$ for the treated group. The values for the nuclei contour index were of 3.68, control, and 3.41, treatment; and for the shape coefficent, the values were 0.93 and 0.91 with $\mathrm{p}>0.05$.

Table III. Values from the kariometry of sustentacular cells nuclei taken from suckling pups whose dams were submitted to application of ofloxacin, and control groups.

\begin{tabular}{lrrrrrrr}
\hline & \multicolumn{3}{c}{ Control group $\mathrm{n}=250$} & \multicolumn{2}{c}{ Treated group $\mathrm{n}=200$} \\
\hline Variables & Media & Sd & Median & Media & $\mathrm{Sd}$ & Median & $\mathrm{p}^{*}$ \\
Major diameter $(\mu \mathrm{m})$ & 1.02 & 0.43 & 13.02 & 14.85 & 0.51 & 14.62 & $\mathrm{~s}$ \\
Minor diameter $(\mu \mathrm{m})$ & 11.24 & 0.35 & 11.02 & 12.49 & 0.61 & 12.29 & $\mathrm{~s}$ \\
Mean geometric diameter & 12.08 & 0.38 & 11.95 & 13.60 & 0.56 & 13.37 & $\mathrm{~s}$ \\
Major/Minor & 1.16 & 0.02 & 1.16 & 1.19 & 0.02 & 1.19 & $\mathrm{~ns}$ \\
Volume $\left(\mu \mathrm{m}^{3}\right)$ & 909.94 & 66.94 & 887.77 & 1260.90 & 172.73 & 1182.00 & $\mathrm{~s}$ \\
Area $\left(\mu \mathrm{m}^{2}\right)$ & 116.94 & 6.65 & 114.89 & 147.35 & 12.41 & 141.68 & $\mathrm{~s}$ \\
Volume/area & 7.49 & 0.23 & 7.35 & 8.33 & 0.40 & 8.19 & $\mathrm{~s}$ \\
Perimeter & 39.52 & 1.27 & 39.33 & 44.81 & 1.66 & 44.01 & $\mathrm{~s}$ \\
Eccentricity & 0.47 & 0.01 & 0.47 & 0.51 & 0.01 & 0.51 & $\mathrm{~s}$ \\
Contour index & 3.69 & 0.01 & 0.38 & 3.71 & 0.01 & 3.41 & $\mathrm{~ns}$ \\
Shape coefficient & 0.92 & 0.008 & 0.93 & 0.91 & 0.009 & 0.91 & $\mathrm{~ns}$ \\
\hline
\end{tabular}

* Mann-Whitney Test; s: significant at a 5\% level; ns: non-significant at a 5\% level.

\section{DISCUSSION}

Lactation, toxicity and rat development. Lactation is a very important period for the growth and development of mammals and one of its main consequences is the reduction in mortality rates. For rats, these two first weeks of life are, as well, crucial (Lopes et al., 1974). An obstacle to the suckling behavior of pups is the use of chemical substances. In general, it is possible to say that most drugs ingested by the dam pass through the milk, generating minimal or potentially harmful effects (Zucolotto \& Marino, 1991).

Because of its own peculiarities, newborn rat pups require constant precautions and vigilance when using drugs. During this special period, when the pup is independent of the dam's metabolism, adaptation to a different environment depends on its own ability to absorb, conjugate, inactivate and excrete substances. The ingestion of chemical elements by the dam during prenatal and suckling periods, along with the factors previously cited, can considerably prolong the half-life of the drug in young organisms (King, 1991).
The $15^{\text {th }}$ day of postnatal life, for the rat, represents a critical moment in testicular development (Rugh, 1968). Studies about drug effects during this period demonstrated alterations indicating toxicity (Azoubel, 1964, Lopes, 1973; Souza et al., 1975; Kempinas et al., 1985).

Despite the capacity of ofloxacin to reach the newborn animal, through the ingestion of dam's milk, this research has only presented alterations at the cellular level.

Organ and target cells (interstitial cells, sustentacular cells and spermatogonias). The karyometric study of Interstitial cells, whose rats were fed by dams exposed to ofloxacin, did not reveal changes in shape and volume. Every variable presented similar data $(p>0.05)$ whenever the treated group and the control group were compared, demonstrating that drug, despite passing from the dam to the pup through suckling, did not cause toxicity, in the utilized dose. 
Insensitivity to the drug may have occurred because interstitial cells were mature. The previous period to this phase was of constant transformation, but, around the $21^{\text {st }}$ day of life, the establishment of interstitial cell populations becomes more mature or differentiated.

Karyometry of spermatogonias from the pups whose dams were treated, revealed similar data between the treated and control groups, $(\mathrm{p}>0.05)$, for every studied parameter, demonstrating that ofloxacin, when administrated to the suckling dam, in the right dosage, does not cause toxicity to these cell nuclei.

On the other hand, different data were found for the karyometric study of sustentacular cells. The major diameter, minor diameter, mean geometric diameter, volume, area, volume/area ratio, and perimeter were augmented $(p<0.05)$. As for eccentricity, it was significantly augmented and statistically different $(\mathrm{p}<$ 0.05 ) in suckling pups whose dams were administered ofloxacin. Because of the increased major and minor diameters, such alterations resulted in nuclei of increased sizes and more elongated shapes.
Shape alteration, slightly more elongated, was only evidenced by eccentricity. The other parameters that evaluated shape did not present significant differences. The major and minor diameters, contour index and shape coefficient were similar to the control group, whose data indicated changes in size and not in nuclei shapes.

Sustentacular cells are important for the development, formation, and characteristics in males. They provide support and protection to germ cells as well as auxiliate their nutrition and the release of mature sperm (Kim et al., 1990).

The increase in sustentacular cells nuclei volumes requires further investigation. Observations about cellular differentiation, sperm formation process, and hormonal dosage may facilitate a broader view of the consequences of nuclear changes found in this study.

The results found in this study suggest the following conclusions: Ofloxacin, during lactation period expands the volume of sustentacular cells nuclei, increasing major diameter by the minor diameter, the area, and the volume; and changes the shape, making eccentricity unequal and diminishing the perimeter.

PASCHOAL, V. D. A.; ROSSIT, A. B.; BIZUTTI, L. O.; MONTEIRO, R.; PADOVANI JR., J. A. \& AZOUBEL, R. Estudio del volumen nuclear de células testiculares de ratas que recibieron ofloxacin durante la lactancia. Int. J. Morphol., 25(3):603-608, 2007.

El ofloxacin presenta un amplio espectro de acción antimicrobiana, incluyendo el combate a Mycobacterium leprae, y es frecuentemente empleado como un sustituto cuando el uso de la rifampicina es imposible. El objetivo del trabajo fue estudiar las alteraciones en el núcleo de las células testiculares en ratas que se encontraban amamantando y que fueron sometidas a la aplicación oral de ofloxacin. El método utilizado fue la técnica morfométrica de la cariometría. Las principales estructuras observadas en las preparaciones histológicas fueron las células intersticiales, espermatogonias y células sustentaculares. Se utilizaron 10 ratas Wistar, cinco fueron el grupo control y cinco sometidas al tratamiento, cuyas madres recibieron ofloxacin en dosis oral diaria de $12 \mathrm{mg} / \mathrm{Kg}$ de peso corporal los primeros 25 días de vida, para luego ser sacrificadas al día 25 después del nacimiento. El estudio cariométrico de las células intersticiales y de la espermatogénesis revelaron que no hubo cambios en la forma de sus núcleos ( $\mathrm{p}>0,05)$. Las células sustentaculares presentaron un incremento en su diámetro mayor, diámetro menor, diámetro geométrico promedio, volumen, área, razón volumen/área y perímetro, también hubo aumento con una diferencia de la excentricidad estadísticamente significativa $(\mathrm{p}<0,05)$ en las crías amamantadas, a las cuales se les administró ofloxacin. Los núcleos presentaron un gran tamaño y una forma más alargada. Esto concluye que las células sustentaculares son más sensibles al efecto de la administración de ofloxacin.

KEY WORDS: Quinolonas; Ofloxacin; Morfología; Cariometría; Volumen nuclear; Testículo; Lactancia; Células Sustentaculares; Rata.

\section{REFERENCES}

Abd-Allah, A. R.; Aly, H. A.; Moustafa, A. M.; Abdel-Aziz, A. A. \& Hamada, F. M. Adverse testicular effects of some quinolone members in rats. Pharmacol. Res.,41(2):2119, 2000.

Azoubel, R. Crescimento alométrico do bulbo ocular durante o desenvolvimento ontogenético da galinha e do rato. [Tese de doutorado] Ribeirão Preto (SP): Faculdade de Medicina de Ribeirão Preto da Universidade de São Paulo, 1964.
Giamarellou, H.; Kolokythas, E.; Petrikkos, G.; Gasis, J.; Aravantinos, D. \& Sfikakis, P. Pharmacokinetics of three newer quinolones in pregnant and lactating women. Am. J. Med., 87(5):490-510, 1989.

Hopkins, W. J.; Elkahwaji, J. E.; Uehling, D.T. \& Leverson, G. E. Phase 2 clinical trial of a vaginal mucosal vaccine for recurrent urinary tract infections in adult women. Abstracts $41^{\text {st }}$ Interscience Conference on Antimicrobial Agents and Chemotherapy. Chicago, dec 16 a19, 2001. 
Kempinas, W. G.; Contrera, M. G. D.; Azoubel, R.; Lopes, R. A.; Sala, M. A. \& Campos, G. M. Hipervitaminose A experimental no rato: estudo volumétrico do ovário de ratas recém-nascidas, durante a lactação. Rev. Esc. Odont. Alfenas, 8:87-97, 1985.

Kim, J. C.; Kim, K. H. \& Chung, M. K. Testicular cytotoxicity of DA-125, a new anthracycline anticancer agent, in rats. Reprod. Toxicol., 13(5):391-7, 1990.

King, F. S. Como ajudar as mães a amamentar. Kenya: African Medical and Research Foundation Wilson Airpot. Londrina, Universidade de Londrina, 1991.

Linseman, D. A.; Hampton, L. A. \& Branstetter, D. G. Quinolone-induced arthropathy in the neonatal mouse: morphological analysis of articular lesions produced by pipemidic acid and ciprofloxacin. Fundam. Appl. Toxicol., 28(10):59-64, 1995.

Lopes, R. A. Efeitos da hipervitaminose A sobre o testículo e o rim do rato durante a lactação: estudo alométrico e histopatológico. [Tese de doutorado]. Ribeirão Preto (SP): Faculdade de Farmácia e Odontologia de Ribeirão Preto da Universidade de São Paulo; 1973.

Lopes, R. A.; Valeri, V.; Azoubel, R.; Iucif, S.; Campos, G. M. Estudo alométrico do testículo do rato submetido a hipervitaminose A, durante a lactação. Rev. Bras. de Pesquisa Méd. e Biol., 7(3):283-91, 1974.

Mayer, D. \& Bruch, K. No indications for the mutagenicity of ofloxacin. Infection, 14(Supl 1):S108-9, 1986.

Meiland, R.; Geerlings, S. E.; Brouwer, E. C.; Coenjaerts, F. E. H.; Langermann, S. \& Hoepelman, I. M. Adherence of Escherichia coli to uroepithelial cells of women with diabetes mellitus can be inhibited by vaccine-induced anti-FimCH anti-serum. Program and abstracts of the $41^{\text {st }}$ Interscience Conference on Antimicrobial Agents and Chemotherapy. Chicago, Illinois. $2001 \mathrm{dec} 16$ a19.

Neu, H. C. Outros fármacos antibacterianos. In: Brady, T. M.; Larner, J.; Minneman, K. P. \& Neu, H. C. Farmacologia humana: da molécula à clínica. $2^{\mathrm{a}} \mathrm{ed}$. Rio de Janeiro, Guanabara Koogan, 1997.

Neu, H. C. Quinolone antimicrobial agents. Ann. Rev. Med., 43:465-86, 1992.

Paschoal, V. D. A.; Azoubel, R.; Batigália, F. \& Paiva, J. V. A. Ofloxacina no tratamento da hanseníase. HB Científica. 10(1):40-7, 2003.
Paschoal, V. D. A. Efeitos da ofloxacina no desenvolvimento dos testículos de ratos: estudo cariométrico [Tese de doutorado]. São José do Rio Preto, SP. Faculdade de Medicina de São José do Rio Preto, 2002. 125 p.

Rugh, R. The Mouse: its reproduction and development. Minneapolis, Burgess Publishing Co., 1968.

Sala, M. A. M.; Matheus, M. \& Valeri, V. A. A new stereological method for estimation: the thickness of a cellular layer on random sections. Mikroskopile Wien, 38(516):127-30, 1981.

Souza, M. L.; Azoubel, R.; Iucif, S. \& Lopes, R. A. Estudo do crescimento do cérebro de ratos submetidos a hipervitaminose A, durante a lactação. Rev. Bras. de Pesquisa Méd. e Biol., 8(1):53-60, 1975.

Stahlmann, R,. \& Lode, H. Toxicity of quinolones. Drugs, 58Supl. 2:37-42, 1999.

Watanabe, T.; Fujikawa, K.; Harada, S.; Ohura, K.; Sasaki, T. \& Takayama, S. Reproductive toxicity of the new quinolone antibacterial agent levofloxacin in rats and rabbits. Arzneimittelforschung, 43(3A):374-7, 1992.

Zucolotto, F. \& Marino, W. T. Alimentação do RN normal. In: Serge CAM, Armellini PA, Marino WT. RN. $3^{\mathrm{a}}$ ed. São Paulo, Sarvier, 1991. Cap 6.

Correspondence to:

Vânia Del 'Arco Paschoal

Rua Rio Negro, 165

CEP 15091-390

Jardim Aclimação

São José do Rio Preto - SP

BRASIL

$\begin{array}{ll}\text { Telephone: } & +55173227-9031 \\ & +5517-3201-5121 \\ & +5517-9149-1077\end{array}$

Email: vania@famerp.br vaniapaschoal@yahoo.com.br

Received: 12-03-2007

Accepted: 25-06-2007 